\title{
PENYULUHAN DAMPAK NEGATIF PENYALAHGUNAAN NARKOBA DI MASYARAKAT
}

\author{
Debie Rizqoh $^{1}$, Rizkianti Anggraini ${ }^{2}$, Diah Ayu Aguspa Dita ${ }^{3}$ \\ ${ }^{1,2,3}$ Fakultas Kedokteran dan Ilmu Kesehatan, Universitas Bengkulu, Bengkulu, Indonesia \\ email: debierizqoh@unib.ac.id ${ }^{1}$,rizkiantianggraini@unib.ac.id ${ }^{2}$,diahayuaguspadita@unib.ac.id ${ }^{3}$
}

\begin{abstract}
The abuse of narcotics, psychotropic substances, and other addictive substances is a problem facing Indonesia, including in Bengkulu City. These users of illicit goods are usually vulnerable or at high risk of afflicting young individuals with unstable personalities. If this is not addressed correctly, it will lead to physical and psychological health problems, low quality of life, disruption of social, economic, cultural functions, and the defense and security of the young generation in the future. The medical sector or health actors have an essential role in controlling drug abuse through promotive, preventive, therapeutic, and rehabilitation efforts. In this case, the authors provide counseling to the community of Pintu Batu Village, Teluk Segara District, Bengkulu City, regarding drugs and forms of drugs to prevent drug use among adolescents and the community.
\end{abstract}

Keywords: Prevention, Abuse, Drugs

\begin{abstract}
Abstrak: Penyalahgunaan narkotika, psikotropika, dan zat adiktif lainya merupakan suatu permasalah yang dihadapi Indonesia tidak terkecuali di Kota Bengkulu dewasa ini. Para pemakai barang haram ini biasanya rentan atau resiko tinggi melanda individu muda yang dengan kepribadian labil. Jika hal ini tidak ditanggulangi dengan baik akan memicu gangguan kesehatan fisik, psikis, rendahnya kualitas hidup, gangguan fungsi sosial, ekonomi, budaya, hankam generasi muda kedepanya. Sektor medis atau pelaku kesehatan mempunyai andil penting dalam iktiar pengendalian penyalahgunaan NAPZA, lewat upaya promotif, preventif, terapi dan rehabilitasi. Dalam hal ini penulis melakukan penyuluhan kepada masyarakat kelurahan Pintu Batu, Kecamatan Teluk Segara, Kota Bengkulu mengenai NAPZA dan bentuk-bentuk NAPZA dalam upaya menagkal penggunaan narkoba dikalangan remaja maupun masyarakat.
\end{abstract}

Kata kunci: Penanggulangan, Penyalahgunaan, NAPZA

\section{Pendahuluan}

Narkotika, psikotropika dan zat adiktif lainya (NAPZA) merupakan golongan senyawa yang lazimnya menyebabkan kecanduan bagi para pemakainya (UndangUndang Nomor 5 tahun 1997; Nomor 22 tahun 1997; Mardani, 2008; BNN, 2017). Proses kecanduan ini akibat adanya rangsangan kamuplase terhadap sensasi, kenikmatan, dan euforia pada pusat penghayatan kenikmatan otak pengguna (Martono \& Joewana, 2006). Persoalan penyalahgunaan barang haram NAPZA atau dikenal juga dilapisan masyarakat dengan julukan NARKOBA ini merupakan persoalan yang sangat serius dan kompleks belakangan ini, sehingga memerlukan usaha pemecahan secara menyeluruh dengan mengaitkan kerja sama antara multisektor, multidispliner dan partisipasi masyarakat secara bersungguh-sungguh yang dilakukan secara konsekuen, konsisten dan berkesinambungan (Hawari, 2000; Maramis, 2005).

Dilain sisi bebarapa golongan narkotika juga dibutuhkan dalam dunia medis sabagai pengobatan. Akan tetapi bila diselewengkan maupun digunakan tidak menurut kebutuhan medis atau standar peruntukanya, apalagi adanya peredaran diranah ilegal akan berdampak sangat merugikan kepada pribadi atau masyarakat umum dan khususnya angkatan muda. Lebih lanjut penyalahgunaan NAPZA secara periodik atau rutin diluar 
kebutuhan medis akan memicu gangguan kesehatan fisik, psikis, rendahnya kualitas hidup, gangguan fungsi sosial, ekonomi, budaya, hankam, penyakit berbahaya HIV/AIDS, dan lain-lain (Donovan et al, 2005; Martono dan Joewana, 2006; Mathers et al, 2007; BNN, 2010; Eleanora, 2011; Azmiyati, 2014; Rodkjaer et al, 2014; Bluthenthal et al, 2015; Sitorus, 2016).

Kencangnya penyimpangan NAPZA sekarang tidak semata-mata terjadi dikota besar saja, namun telah merambah daerah dan pelosok diseluruh belahan Republik Indonesia, dan penggunaya berangkat dari jenjang ekonomi bawah menengah hingga drajat status sosial ekonomi atas. Dari laporan United Nation on Drug and Crime (2017) mengestimasi pada tahun 2015 yang lalu kurang lebih 255 juta orang (5\% dari penduduk usia dewasa 15-64 tahun) pernah mengonsumsi narkoba minimalnya sekali. Lebih lanjut survei yang di adakan BNN dan P2K UI memaparkan malfungsi narkoba ditahun 2005 dan 2010 pada tataran rumah tangga adalah 2,4\% (1 dari 42 rentang usia 10-59 tahun) sempat mencicipi narkoba setidaknya satu kali dalam hidupnya (BNN, 2008; BNN dan PPK UI, 2010). Sedangkan pada tataran pelajar disampaikan empat dari sepuluh pelajar atau mahasiswa sudah memanfaatkan narkoba dan sebagian jumlah tersebut menggunakannya pada rentang setahun terakhir (BNN, 2016).

Penyalahgunaan narkoba pada kalangan generasi muda merupakan pasar menjanjikan dalam perdagangan gelap NAPZA. Data yang ada diatas memberikan peringatan keras kepada semua pihak guna mewaspadai dan menagkal ancaman dan efeknya terhadap kelangsungan kwalitas angkatan muda kedepan. Pelaku dan praktisi sektor kesehatan mempunyai andil penting dalam iktiar pengendalian penyimpangan NAPZA, lewat upaya penyuluhan, pencegahan, terapi dan rehabilitasi (Hawari, 2000; Maramis, 2005). Kedudukan penting area kesehatan ini kerap tidak dimengerti oleh personel medis itu sendiri. Sektor ini penting dikembangkan dengan lebih profesional, sehingga berperan sebagai salah satu benteng yang kokoh dalam upaya penanggulangan penyimpangan NAPZA didaerah - daerah negara kesatuan Republik Indonesia.

Peredaran NAPZA diwilayah Indonesia yang dijelaskan sebelumnya juga telah menyebar tidak terkecuali di wilayah Bengkulu. Berdasarkan laporan dari BNN di Kota Bengkulu jumlah penyalahguna sebanyak 24,118, prevelansi 1.68 dari jumlah penduduk (10-59) 1,436,700 (BNN, 2017). Saat ini sebagian besar penghuni lembaga pemasyarakatan di Kota Bengkulu merupakan para pecandu narkoba. Hal tersebut mengindikasikan bahwa Kota Bengkulu saat ini dalam status darurat narkoba. Oleh sebab itu, penyuluhan terhadap penyalahgunaan narkoba perlu dilaksanakan guna menanggulangi masalah tersebut.

\section{Metode}

Masalah utama yang ingin dipecahkan dalam pengabdian kepada masyarakat ini berhubungan dengan penyuluhan penyalahgunaan dan bahaya penggunan NAPZA. Kegiatan ini mendukung program Badan Narkotika Nasional (BNN) dalam rangka melawan dan penanggulangan penyalahgunaan narkoba. Diharapkan dengan kegiatan ini, masyarakat Kota Bengkulu khususnya di Kelurahan Pintu Batu semakin tercerahkan 
dengan informasi mengenai dampak negatif penyalahgunaan NAPZA.

Kegiatan yang dilakukan melibatkan Universitas Bengkulu, Perangkat Kelurahan dan Masyarakat Kelurahan Pintu Batu, Kecamatan Teluk Segara, Kota Bengkulu. Seluruh tim pelaksana kegiatan ini adalah dosen pada Program Studi Pendidikan Dokter, Fakultas Kedokteran dan Ilmu Kesehatan UNIB yang terdiri dari 3 orang dosen dan narasumber.

Pelaksana kegiatan ini mempersiapkan segala sesuatu yang dibutuhkan demi terlaksananya kegiatan dengan lancar dan sukses. Untuk pendekatan dan metode yang digunakan untuk menggapai tujuan penyuluhan ini bisa dilihat di Tabel 1, dan adapun peran masing-masing pihak diuraikan di Tabel 2 dibawah ini.

Tabel 1. Tujuan dan Metode Penyuluhan

\begin{tabular}{|c|c|c|c|}
\hline No. & Tujuan & Metode & Bentuk Kegiatan \\
\hline 1 & $\begin{array}{l}\text { Perlu menyampaikan } \\
\text { pengetahuan berkenaan apa } \\
\text { itu NAPZA kepada } \\
\text { masyarakat di Kel. Pintu } \\
\text { Batu Kota Bengkulu. }\end{array}$ & $\begin{array}{c}\text { Ceramah } \\
\text { dan } \\
\text { Diskusi }\end{array}$ & $\begin{array}{l}\text { Penyuluhan kepada masyarakat Kel. } \\
\text { Pintu Batu, Kecamatan Teluk Segara, } \\
\text { Kota Bengkulu mengenai NAPZA dan } \\
\text { bentuk-bentuk NAPZA }\end{array}$ \\
\hline 2 & $\begin{array}{l}\text { Untuk memberi } \\
\text { pemahaman tentang } \\
\text { dampak negatif } \\
\text { penyalahgunaan NAPZA } \\
\text { kepada masyarakat di Kel. } \\
\text { Pintu Batu Kota Bengkulu } \\
\text { agar masyarakat ikut serta } \\
\text { dalam usaha } \\
\text { penanggulangan NAPZA }\end{array}$ & $\begin{array}{c}\text { Ceramah } \\
\text { dan } \\
\text { Diskusi }\end{array}$ & $\begin{array}{l}\text { Penyuluhan kepada masyarakat Kel. } \\
\text { Pintu Batu, Kecamatan Teluk Segara, } \\
\text { Kota Bengkulu mengenai dampak negatif } \\
\text { penyalahgunaan NAPZA dan usaha yang } \\
\text { dapat dilakukan dalam mencegah } \\
\text { penyalahgunaan NAPZA dalam } \\
\text { lingkungan keluarga. }\end{array}$ \\
\hline
\end{tabular}

Tabel 2. Kedudukan Masing-Masing Pihak Yang Berpartisipasi Dalam Kegiatan

\begin{tabular}{|c|c|c|}
\hline Tim Pelaksana Pembinaan UNIB & \multicolumn{2}{|c|}{ Perangkat Kelurahan Pintu Batu } \\
\hline $\begin{array}{l}\text { Melakukan observasi terhadap khalayak } \\
\text { sasaran }\end{array}$ & \multicolumn{2}{|c|}{$\begin{array}{l}\text { Menyediakan informasi dan data tentang } \\
\text { kondisi calon mitra }\end{array}$} \\
\hline Membuat rancangan kegiatan & \multicolumn{2}{|c|}{$\begin{array}{l}\text { Menyiapkan anggota masyarakat sebagai } \\
\text { peserta penyuluhan }\end{array}$} \\
\hline Merancang metode pelaksanaan & \multicolumn{2}{|c|}{ Menyiapkan lokasi pelaksanaan kegiatan } \\
\hline $\begin{array}{l}\text { Menyiapkan materi kegiatan dan } \\
\text { Narasumber }\end{array}$ & $\begin{array}{l}\text { Menyiapkan } \\
\text { penyuluhan }\end{array}$ & pelaksanaan \\
\hline $\begin{array}{l}\text { Memberi bimbingan dan feedback kepada } \\
\text { masyarakat terhadap materi yang } \\
\text { disampaikan narasumber }\end{array}$ & $\begin{array}{l}\text { Menyiapkan } \\
\text { penyuluhan }\end{array}$ & pelaksanaan \\
\hline $\begin{array}{l}\text { Merancang dan melaksanakan evaluasi } \\
\text { kegiatan }\end{array}$ & $\begin{array}{l}\text { Menyiapkan } \\
\text { penyuluhan }\end{array}$ & pelaksanaan \\
\hline
\end{tabular}




\section{Rancangan Evaluasi}

Pada proses dan produk kegiatan ini diterapkan rancangan evaluasi, pada evaluasi proses direalisasikan selama kegiatan berlangsung dan poin yang dievaluasi bersentuhan dengan kehadiran, antusiasme peserta menyertai kegiatan, dan kerjasama. Sedangkan untuk evaluasi produk diterapkan terhadap pengetahuan yang peserta dapatkan selama penyuluhan yang dituangkan dalam bentuk kusioner yang diambil pada sesi akhir kegiatan. Tolak ukur keberhasilan kegiatan ini apabila respon positif peserta dalam proses kegiatan berlangsung dan terjadi peningkatan pengetahuan peserta terhadap penyalahgunaan NAPZA sebelum dan sesudah diberikannya penyuluhan yang dapat dilihat dari pengerjaan kuisioner yang tersedia dalam bentuk hardcopy untuk di isi secara manual. Hasil pengisian kuisioner tersebut langsung diurai dan diaparkan dalam bentuk tabel.

\section{Hasil dan Pembahasan}

Program kegiatan pengabdian ini diberikan kepada warga yang tinggal di Kelurahan Pintu Batu, Kecamatan Teluk Segara, Kota Bengkulu, diselenggarakan pada tanggal 5 Desember 2019, pukul 09.00 s.d selesai, bertempat di Ruang Pertemuan Kantor Kelurahan. Kegiatan ini dimulai dengan pembukaan dan perkenalan dengan tim pelaksana, sekaligus menyampaikan tujuan kegiatan ini. Selanjutnya diberikan penyuluhan tentang NAPZA dan dampak negatifnya bagi generasi bangsa yang disampaikan oleh narasumber dr. Riqianti Anggraini selaku ketua kegiatan ini dengan latar belakang dokter umum kepada peserta penyuluhan. Setelah penyampaian materi kegiatan, agenda kegiatan diteruskan dengan tukar pikiran dan wawancara antara peserta dan narasumber mengenai materi penyuluhan. Acara dilanjutkan dengan evaluasi pengetahuan peserta melalui pengisian kuisioner dalam bentuk formulir yang diisi secara manual, lalu diakhiri dengan penutupan.

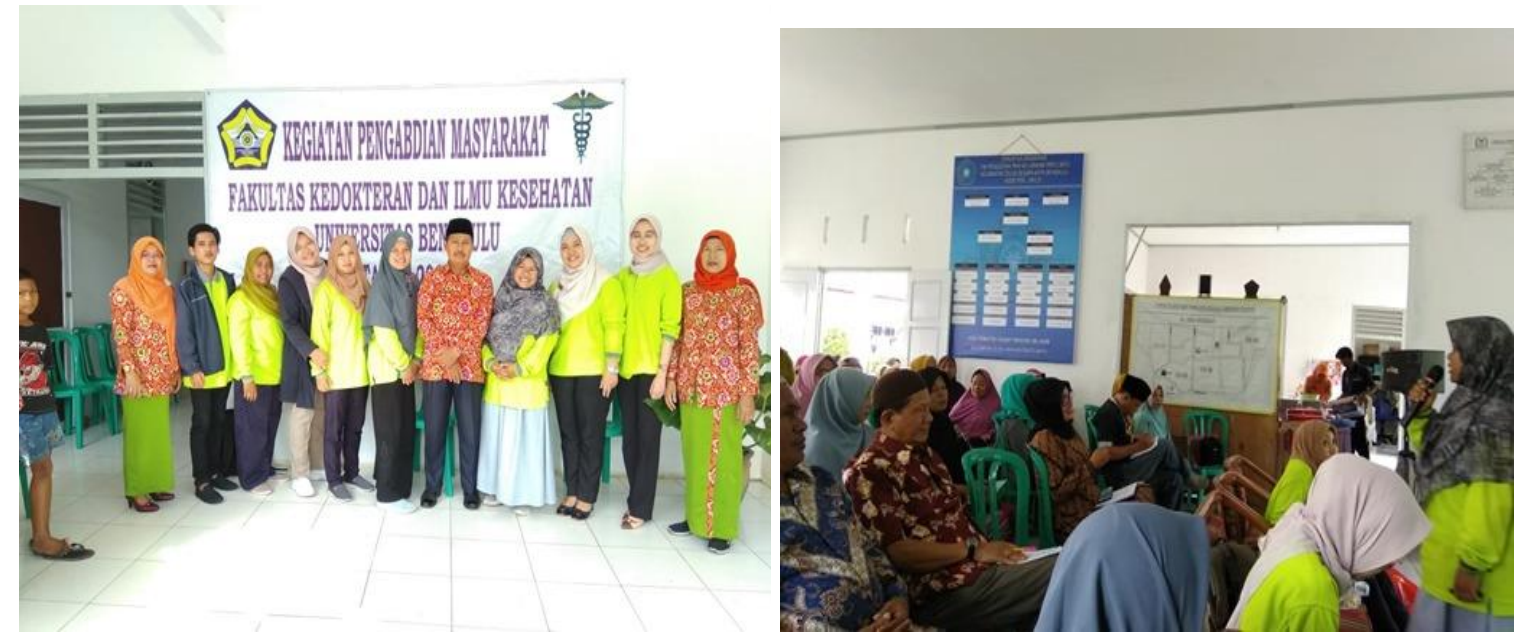

Gambar 1. Proses Kegiatan Penyuluhan

Masyarakat Kelurahan Pintu Batu terlihat antusias dalam mengikuti proses acara penyuluhan dari awal hingga akhir kegiatan. Kondidisi ini terlihat dari kehadiran masyarakat, perhatian penuh saat pemaparan materi oleh narasumber dan banyaknya respon pertanyaan dan tanggapan masyarakat saat diskusi, karena keterbatasan waktu 
tidak semua peserta mendapat kesempatan untuk bertanya. Adapun kerjasama antara panitia dan pihak perangkat kelurahan berjalan baik. Hal tersebut terlihat dari bantuan perangkat desa untuk mengundang masyarakat, menyediakan tempat pelaksanaan, menyediakan konsumsi dan ikut serta membantu pendanaan dalam kegiatan penyuluhan tersebut. Bahkan dalam acara tersebut turut juga mengundang Camat Kecamatan Teluk Segara yang ikut memberikan sambutan pada acara penyuluhan ini.

Evaluasi produk dalam penyuluhan ini dilakukan dengan melaksakan pre-test yang dilaksanakan sebelum pemaparan materi dan post-test setelah selesai terhadap peserta penyuluhan dengan mengedarkan daftar pertanyaan formatif (Tabel 3). Berdasarkan hasil pre-test, pengetahuan masyarakat tentang NAPZA secara terlihat sudah cukup baik (Tabel 4) dimana hampir semua pertanyaan (kecuali no. 2) persentase jawaban benar cukup tinggi 67\%-89\%. Dan persentase jawaban yang benar tersebut umumnya meningkat setelah diberi paparan penyuluhan berdasarkan hasil post-test (Tabel 5).

Diantara semua soal, hanya soal no.2 yang kurang dipahami oleh masyarakat, yaitu tentang penggolongan jenis narkoba berdasarkan efek psikologis yang ditimbulkan. Namun secara keseluruhan, tujuan dari penyuluhan ini berhasil meningkatkan pemahaman masyarakat tentang dampak negatif penyalahgunaan NAPZA.

Tabel 3. Daftar Pertanyaan Formatif untuk Peserta

\begin{tabular}{llc}
\hline No. & Soal & Jawaban \\
\hline 1. & Lem aibon termasuk NAPZA. & B \\
2. & Heroin merupakan salah satu jenis obat yang menimbulkan & S \\
& halusinasi. & B \\
3. $\quad$ Salah satu bentuk pemakaian putaw adalah seperti rokok. & B \\
4. $\quad \begin{array}{l}\text { Salah satu efek negatif narkoba terhadap susunan saraf pusat } \\
\text { adalah antisosial. }\end{array}$ & B \\
\hline
\end{tabular}

Tabel 4. Respon Pre-Test Peserta Penyuluhan Dampak Negatif Narkoba

\begin{tabular}{lcc}
\hline No. Pertanyaan & Persentase Jawaban Benar & Persentase Jawaban Salah \\
\hline 1 & $68 \%$ & $32 \%$ \\
2 & $9 \%$ & $91 \%$ \\
3 & $67 \%$ & $33 \%$ \\
4 & $89 \%$ & $9 \%$ \\
5 & $76 \%$ & $14 \%$ \\
\hline
\end{tabular}

Tabel 5. Respon Pre-Test Peserta Penyuluhan Dampak Negatif Narkoba

\begin{tabular}{lcc}
\hline No. Pertanyaan & Persentase Jawaban Benar & Persentase Jawaban Salah \\
\hline 1 & $86 \%$ & $12 \%$ \\
2 & $8 \%$ & $92 \%$ \\
3 & $67 \%$ & $33 \%$ \\
4 & $91 \%$ & $9 \%$ \\
5 & $92 \%$ & $8 \%$ \\
\hline
\end{tabular}




\section{Kesimpulan}

Kegiatan penyuluhan tentang dampak negatif NAPZA di Kelurahan Pintu Batu, Kecamatan Teluk Segara, Kota Bengkulu telah berjalan dengan baik. Pemahaman masyarakat tentang bahaya narkoba sudah sangat baik dan bahkan masyarakat bersemangat dalam ikut serta mendukung program pemerintah dalam membasmi narkoba, terlihat dari antusiasme dan keinginan yang disampaikan masyarakat saat penyuluhan berlangsung. Kegiatan pengabdian ini dalam rangka ikut memberantas narkoba, selanjutnya tidak berhenti sampai dengan penyuluhan saja, namun sebaiknya juga ikut bekerjasama dengan Badan Narkotika Nasional (BNN) dan masyarakat dalam menyukseskan program pemberantasan narkoba dan penanganan masyarakat pecandu narkoba di Indonesia.

\section{Ucapan Terima Kasih}

Ucapan terima kasih dikirimkan kepada pimpinan dan civitas Fakultas Kedokteran dan Ilmu Kesehatan Universitas Bengkulu yang telah membantu pendanaan untuk pelaksanaan aktivitas pengabdian masyarakat ini, dan semua pihak yang ikut serta dalam program penyuluhan bahaya penyalahgunaan NAPZA ini.

\section{Daftar Pustaka}

Azmiyati, SR, dkk. (2014). Gambaran penggunaan NAPZA pada anak jalanan di Kota Semarang. Jurnal Kesehatan Masyarakat (KEMAS), 9(2), 137-143.

DOI:https://doi.org/10.15294/kemas.v9i2.2841

Bluthenthal, R. N., Wenger, L., Chu, D., Lorvick, J., Quinn, B., Thing, J. P., \& Kral, A. H. (2015). Factors associated with being asked to initiate someone into injection drug use. Drug and alcohol dependence, 149, 252-258. https://doi.org/10.1016/j.drugalcdep.2015.02.011

BNN RI. (2008). Petunjuk Teknis Advokasi Bidang Pencegahan Penyalahgunaan Narkoba. Jakarta: Badan Narkotika Nasional.

BNN RI dan Pusat Penelitian Kesehatan UI. (2010). Survei Nasional Penyalahgunaan dan Peredaran Gelap Narkoba di Indonesia. Jakarta: Badan Narkotika Nasional.

BNN RI. (2010). P4GN Bidang pemberdayaan masyarakat. Jakarta: Badan Narkotika Nasional.

BNN RI. (2016). Hasil Survei Penyalahgunaan dan Peredaran Gelap Narkoba pada Kelompok Pelajar Mahasiswa di 18 Provinsi Tahun 2016. Jakarta: Badan Narkotika Nasional.

BNN RI. (2017). Survei Nasional Penyalahgunaan Narkoba Di 34 Provinsi Tahun 2017. Jakarta: Badan Narkotika Nasional.

Donovan, D., Mattson, M. E., Cisler, R. A., Longabaugh, R., \& Zweben, A. (2005). Quality of life as an outcome measure in alcoholism treatment research. Journal of studies on alcohol. Supplement, 15, 119-93.

https://doi.org/10.15288/jsas.2005.s15.119

Eleanora, F.N. (2011). Bahaya Penyalahgunaan Narkoba serta Usaha Pencegahan dan Penanggulangannya. Jurnal Hukum, 25(1), 440-441.

DOI: http://dx.doi.org/10.26532/jh.v25i1.203

Hawari, D. (2000). Penyalahgunaan Narkotika dan Zat Aditif. Jakarta: Fakultas 
Kedokteran Universitas Indonesia.

Mardani. H. (2008). Penyalahgunaan Narkoba Dalam Perspektif Hukum Islam Dan Hukum Pidana Nasional. Jakarta: PT. Raja Grafindo Persada.

Maramis, W.F. (2005). Catatan Ilmu Kedokteran Jiwa. Surabaya : Airlangga University Press.

Martono, L.H. \& Joewana, S. (2006). Modul Latihan Pemulihan Pecandu Narkoba Berbasis Masyarakat. Jakarta: Balai Pustaka.

Martono, L.H. dan Joewana, S. (2006). Pencegahan Dan Penanggulangan penyalahgunaan narkoba berbasis sekolah. Jakarta: Balai Pustaka.

Mathers, B. M., Degenhardt, L., Phillips, B., Wiessing, L., Hickman, M., Strathdee, S. A., Wodak, A., Panda, S., Tyndall, M., Toufik, A., Mattick, R. P., \& 2007 Reference Group to the UN on HIV and Injecting Drug Use (2008). Global epidemiology of injecting drug use and HIV among people who inject drugs: a systematic review. Lancet (London, England), 372(9651), 1733-1745. https://doi.org/10.1016/S0140-6736(08)61311-2

Rodkjaer, L., Chesney, M. A., Lomborg, K., Ostergaard, L., Laursen, T., \& Sodemann, M. (2014). HIV-infected individuals with high coping self-efficacy are less likely to report depressive symptoms: a cross-sectional study from Denmark. International Journal of infectious diseases: IJID: official publication of the International Society for Infectious Diseases, 22, 67-72. https://doi.org/10.1016/j.ijid.2013.12.008

Sitorus, R. J. (2015). Pengaruh Tahapan Rebilitasi Self Efficacy Pasien Keteragantungan di Pusat Terapi dan Rehabilitasi Lido. Depok: Universitas Indonesia.

UNODC. (2017). World Drug Report 2017: Global Overview of Drug Demand and Supply. Vienna: United Nation Office on Drugs and Crime.

Undang-Undang Negara Republik Indonesia Nomor 22 Tahun 1997 Tentang Narkotika Undang-Undang Negara Republik Indonesia Nomor 5 Tahun 1997 Tentang Psikotropika 